(2) Renaissance Quarterly

The Renaissance Society of America

The Graduate School and University Center

The City University of New York 


\section{BOOK HISTORY}

From the British Library

Discovering, Identifying and Editing Early Modern Manuscripts

English Manuscript Studies

1100-1700, Volume 18

\section{Edited by Peter Beal}

This latest volume in the British Library's prestigious series on the history of the manuscript in English comprises ten articles on a diverse range of texts and authors, including the "Feathery Scribe," Leicester's Commonwealth, Robert Herrick, the Earl of Rochester, and John Locke.

Cloth $\$ 75.00$

\section{From the Bodleian Library, University of Oxford

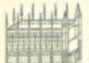 Bodleian Library \\ Latin Liturgical Psalters in the Bodleian Library}

\section{A Select Catalogue}

\section{Elizabeth Solopova}

Latin Liturgical Psalters in the Bodleian Library describes more than

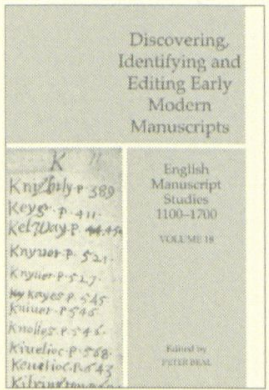
one hundred psalters from Britain, France, the Netherlands, Germany,

Austria, Italy, and Spain, ranging from the ninth to the sixteenth century and reflecting a wide range of requirements and interests.

Cloth $\$ 300.00$

\section{From the Joseph Regenstein Library, ‥"Llbrary The University of Chicago \\ Homer in Print}

A Catalogue of the Bibliotheca Homerica Langiana at the University of Chicago Library

\section{Edited by Glenn W. Most and Alice Schreyer}

With Essays by M. C. Lang, Glenn W. Most, and David Wray, and Entries by Alex Lee and Diana Moser

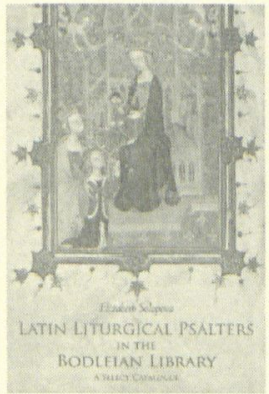

Homer in Print traces the print transmission and literary reception of the Iliad and the Odyssey from the fifteenth through the twentieth century. More than 175 mini-essays provide new details of each edition's textual, intellectual, and publishing history.

Cloth $\$ 55.00$

Distributed by the University of Chicago Press www.press.uchicago.edu 